\title{
A Critical Review of "the Mesolithic" in Relation to Siberian Archaeology
}

\author{
ALEXANDER B. DOLITSKY ${ }^{1}$
}

\begin{abstract}
This paper explores the potential of the economic-ecological method based on the exploitation of fish resources for Mesolithic site identification, as compared to the recently popular yet indecisive technological-typological method, to predict the existence of "Mesolithic-like" subsistence activities in Siberia during the Sartan-Holocene "transition" period. The article is an attempt to establish, or at least to propose, new criteria that can lead to a higher level of understanding of Mesolithic economies in subarctic and arctic regions. Also, decision-making processes that operate to achieve behavioral goals based on efficiency of human beings are suggested. The model, designed with respect to geographical regions identified as interbiotic zones, has the advantage of offering specific alternative hypotheses enabling the definition of both environmental properties and predicted human behavior.
\end{abstract}

Key words: Mesolithic, Siberia, interbiotic zone

RÉSUMÉ. L'article étudie le potentiel de la méthode économique-écologique fondée sur l'exploitation de poissons en guise de ressources pour l'identification de sites mésolithiques, en comparison avec la méthode technologique-typologique populaire mais indécise, afin de prédire l'existence d'activités de subsistence de genre mésolithique en Sibérie durant la période de transition Sartan-Holocène. On tente d'établir ou au moins de proposer de nouveaux critères qui pourraient permettre une meilleure compréhension des économies mésolithiques dans les régions arctiques et subarctiques. De plus, on suggère des processus de prise de décisions qui visent à établir des buts de comportement fondés sur l'efficacité de l'être humain. Conçu par rapport à des régions géographiques nommées zones interbiotiques, le modèle a l'avantage d'offrir des choix particuliers d'hypothèses permettant la définition des propriétés environnementales et du comportement humain prévu.

Mots clés: mésolithique, zone interbiotique

Traduit pour le journal par Maurice Guibord.

\section{INTRODUCTION}

This paper suggests an economic-ecological method of analysis for the identification of the Sartan-Holocene archaeological sites in Cis-Baykal. This method is based on the theoretical assumption that adaptive processes, or long-term changes, are a result of adaptive, short-term strategies of early hunters to obtain and use fishing subsistence resources. Longtime adaptive processes can be explained as the movement of human activities into "specialized locations depending on the availability of particular natural resources" (Bennett, 1969:14). Accepting Bennett's definition of adaptive strategy, I shall attempt to explain the behavioral mechanism of hunters and gatherers in their habitat, i.e., the relationships between human subsistence regimes and environmental quality, and why man chooses a certain location for living. By using Bennett's concept of adaptive processes, I would like to suggest a method for identification of a Mesolithic economy in arctic and subarctic regions.

It is possible that the Siberian archaeological traditions of the Late Pleistocene-Early Holocene period can be related socioeconomically and chronologically to the Eurasian Mesolithic. The Mesolithic in the Old World, just as the SartanHolocene "transition" period in Siberia, belongs to the time of dramatic deglaciation, climatic change and extensive appearance of new subsistence resources characterized by medium- and small-size, fast-running animals and rich freshwater resources. The interaction of early hunters with new subsistence resources probably directly affected their adaptive strategy, resulting in a new socioeconomic level that included a new lithic technology, geographical variability of site loca- tions and site morphology, and a new type of social organization of early hunting groups.

This paper criticizes the traditional way of classification of archaeological assemblages, sites or stages often employed by the comparative technological-typological method of analysis, suggested first over 100 years ago by a brilliant French archaeologist, De Mortillet. In classifying archaeological data, it seems more appropriate to me to consider first the relationship of human groups to their subsistence needs, inferring rational principles of human economic behavior. Artifacts, technology, dwellings, etc., are the result of human-environment interactions and can be very similar even when there are no geographical or intellectual contacts between people (broadly similar archaeological material can be found in western Europe, Africa and North America). Probably material culture is more similar where the behavioral or adaptive strategies within ecosystems are alike. In this paper, I intend to suggest an explanatory-predictive subsistence model, namely the interbiotic zone, for the identification of Mesolithic sites in northern latitudes based on the exploitation of fish resources. This article proposes new criteria that can lead to a new level of understanding of Mesolithic economies in subarctic and arctic regions.

\section{CLASSIFICATION OF THE MESOLITHIC}

There is disagreement among archaeologists concerning the temporal placement and definition of the Mesolithic period. Some archaeologists (Childe, 1957; Rogachev and Okladnikov, 1966, cited in Matyushin, 1976) have suggested the 
term "Epipaleolithic" or "Paleolithic of Holocene" instead of the term "Mesolithic." They also have suggested combining the Mesolithic and Paleolithic periods into a single cultural-historical unit, arguing that there is no significant technological difference between these periods. Others strongly oppose the joining of the two periods, suggesting that the Mesolithic is better termed as "preceramic Neolithic" and thus should be included with the Neolithic stage. A last group of archaeologists (Efimenko, 1953; Martynov, 1981; Matyushin, 1976; and Chernysh, 1975) consider the Mesolithic to be a separate period, representing the transition of Paleolithic forms of subsistence to the Neolithic ones. They argue that such a transition came about because socioeconomic preconditions for the transition of food-gathering to food-producing activities were established during the Mesolithic period.

The significance of the Mesolithic is that it was a crucial period during which the mode of production changed and people began to play a major role in their relationships to the environment (Dolukhanov and Khotinsky, 1974). Under the term "mode of production" Soviet researchers usually mean the entity of four interrelated processes: technical (transmission and transformation of energy from one form into another); technological (transformation of raw material into accomplished products); organizational (spatial and temporal coordination of all elements of production); and economic (coordination of interests of a subject of production and of economy forming a whole) (Semenov and Korobkova, 1983). Most archaeologists find it productive to define the Mesolithic as the transitional period. During the Mesolithic, socioeconomic conditions developed that effected the transition from the Paleolithic food-gathering stage to the Neolithic food-producing stage. Simultaneously with this change the new subsistence technology developed. One of the significant factors of Mesolithic economy was the appearance of a geometric microlithic technology, which developed with the utilization of woodland resources by early hunters and gatherers (Matyushin, 1976). Fishing was another important factor of Mesolithic economy. It was first practiced systematically in this period (G. Clark, 1952, 1972). These two major practices of Mesolithic economy have led researchers to look for specific criteria for the identification of Mesolithic sites.

In the past 30 years, archaeologists have attempted to modify the standard classification of Mesolithic sites. For example, Braidwood (1960) suggested reconsidering some traditionally established terms in archaeology, such as Paleolithic, Mesolithic, and Neolithic, and argued that these divisions are artificial and do not properly solve the problems of socioeconomic development and of adaptations of early hunters and gatherers to their environment. He proposed three stages for the history of humankind: food-gathering, food-producing, and industrial. According to Braidwood, the first stage took place in the Paleolithic and early Mesolithic periods. The second stage covered the rest of human history from the end of the Mesolithic to the eighteenth century A.D. The third stage began just 200 years ago and continues to the present. Braidwood noticed that by the end of the food-gathering stage (Mesolithic), certain preconditions (favorable environmental conditions, sedentary mode of life, population growth, domestication of middle-sized grassland animals) had arisen that were necessary for the introduction of the food-producing era.

G. Clark $(1952,1972)$ proposed a different approach to the classification of the Mesolithic in a number of his publications. He suggested distinguishing the Mesolithic from other stages by treating it chronologically. According to Clark, the Mesolithic began in the Holocene period (about $8000-8300$ years B.P.) in Europe and continued for almost 3000 years, until the climate in Europe and Asia finally stabilized. Clark's classification seems reliable. However, some archaeologists do not agree with him. Kozlowski (1973) suggests the Mesolithic be considered from a economic-ecological point of view. Although he agrees that the Mesolithic began in Europe during the Early Holocene, he also believes that a Mesolithic type of economy could develop in different geographical regions and chronological periods. He sees its development as a result of the tundra hunter's adaptation to a woodland ecosystem, established during the early Holocene in the European lowlands. Thus, Kozlowski (also see Bader, 1974) identifies the Mesolithic only where tundra habitats were replaced by woodland ones. To me, the economic-ecological approach to Mesolithic classification seems more useful than the chronological one. However, it must not be claimed that the development of Mesolithic traditions was limited to Eurasian woodland zones alone.

Recently, Price (1983) suggested a provocative definition of the term Mesolithic. To Price (1983:762) "the Mesolithic is not associated exclusively with the utilization of microlithic tools, nor with the exploitation of forests and coasts, nor with the domestication of the dog," but it is the "period of the Postglacial prior to the introduction of agriculture." Thus, it follows that Price's definition of the term Mesolithic is appropriate to certain regions of northeastern Europe (Gurina $e t$ al., 1974; Savukinene and Seybutis, 1974; Andrianov, 1974; Pankrushev, 1978; Zhuravlev, 1983) and Siberia (Matyushin, 1976; Starkov, 1980; Konopatsky, 1982; Okladnikov, 1983) where agriculture was not successfully developed until recently. Price's arguments for the definition of the Mesolithic are relevant to the archaeological assumptions proposed in this paper and are applicable to the data described below. The reconsideration of the northern Neolithic, Bronze and Iron stages can also be proposed for future studies. Presence/ absence of pottery, for example (pottery was found in Japan in the Late Pleistocene deposits and dated by C 14 up to 12000 years), should no longer be an indicator for Neolithic economy, i.e., food-producing stage, in the North, but the development of agriculture, complete sedenterism and the emergence of complex society. Evidently, food-producing economy was not introduced in Siberia and the Far East until the Russian occupation.

According to Matyushin (1976), man utilized subsistence resources differently in different geographical regions, since the physical environment, and particularly the climate, had varied effects on human adaptive processes. In certain geographical regions pastoralism played an important role, while in others hunting and fishing were most important. Dif- 
ferences in the utilization of local resources influenced the direction of particular socioeconomic developments. For example, habitat changes in the north during the second half of the Würm (Sartan) glacial period were the result of climatic changes and rapid deglaciation (Tseytlin, 1979). However, in the south climatic changes may have caused decreases of the animal biomass and grassland mammals may have migrated to the north (Bader, 1974). Some hunters and gatherers followed the migrating animals northward, transferring the Mesolithic technology to new regions. According to Dolukhanov and Khotinsky (1974) and Matyushin (1976), new forms of economy and subsistence resources were therefore developed during the Mesolithic period, while in some geographical areas (the Arctic, Tropics, etc.) this socioeconomic process was delayed because of environmental circumstances. In some refuge areas the Mesolithic socioeconomy exists at the present.

\section{THE SIBERIAN MESOLITHIC}

There are major difficulties in the identification of the Mesolithic as it relates to northern regions, for geometric microlithic technology is not evident in European and Siberian arctic sites. This, however, does not prevent the conclusion that a Mesolithic economy was present in the arctic and subarctic regions in the past (Gurina et al., 1974; Bader, 1974; Khlobystin and Levkovskaya, 1974; Okladnikov, 1983; Zhuravlev, 1983).

\section{A Critical Application of Deterministic Models for the Analysis of the Siberian Mesolithic}

Researchers often analyze archaeological sites and make conclusions about traditions and stages using a previously established paradigm. The unquestioning acceptance of their assumptions and principles places these researchers in a difficult position, since sometimes new data are not in harmony with traditionally established criteria. Unfortunately, many archaeologists are strongly influenced by generally accepted scientific principles and stereotypes. They attempt to examine the principles of human adaptive strategy on the level of simple descriptions of spatial patterns and regional units, rather than to explain the complexity of human activity within their environment. In short, such determinists attempt to formulate a generalization first and to sample selectively in order to demonstrate that the generalization is applied universally to all human societies. For example, Harris (1968:4) postulates that:

... similar technologies applied to similar environments tend to produce similar arrangements of labor in production and distribution, and that these in turn call forth similar kinds of social groupings, which justify and coordinate their activities by means of similar systems of values and beliefs. Translated into a research strategy, the principle of techno-environmental or techno-economic determinism assigns priority to the study of the material conditions of sociocultural life, much as the principle of natural selection assigns priority to the study of differential reproductive success.

As we see, Harris is operating at a very general level. $\mathrm{He}$ calls his approach "nomothetic," meaning that it aims at broad generalities, not description of any particular culture. However, from the perspective of archaeological analysis Harris's general statement is not always applicable to the specific technological-typological classifications of the archaeological assemblages. It is known empirically that similar physical environments are used differently, and different physical environments are used similarly. For example, West European Mesolithic implements and North American Denbigh tradition tend to look typologically alike (Giddings, 1967; my observation of Denbigh and West European Mesolithic collections), despite the differences in their physical environments. By contrast, southeastern Chinese and southeastern United States inhabitants or desert Beduins and desert hunters/gatherers look very different ethnographically and archaeologically, despite the close similarity of their physical environments, because of the great cultural and technical differences between their respective individuals, as reflected in their culture (Murphey, 1972; Gould, 1982, pers. comm.). These examples support the alternative that different people look for different results, and vice versa.

It is probable that the traditional technological-typological approach for the classification of Siberian archaeological sites during the Holocene prevents archaeologists from recognizing several significant traits of the Mesolithic economy. Some Siberian archaeological sites, however, such as Ust' Belaya, Verkholenskaya Gora, Cheremushnik, Baday, Ulan-Khada, Shishkino Village, Khina and Chastye, as well as some sites in the Soviet Far East (Tadusha) and southeastern Chukchi Peninsula (Fig. 1) have been proposed as the transitional Paleolithic-Mesolithic sites on the bases of technologicaltypological differences (presence of western Mesolithic-like arrowheads, retouched microblades and microblade points, burins, prismatic microcores, earliest mother-of-pearl beads,

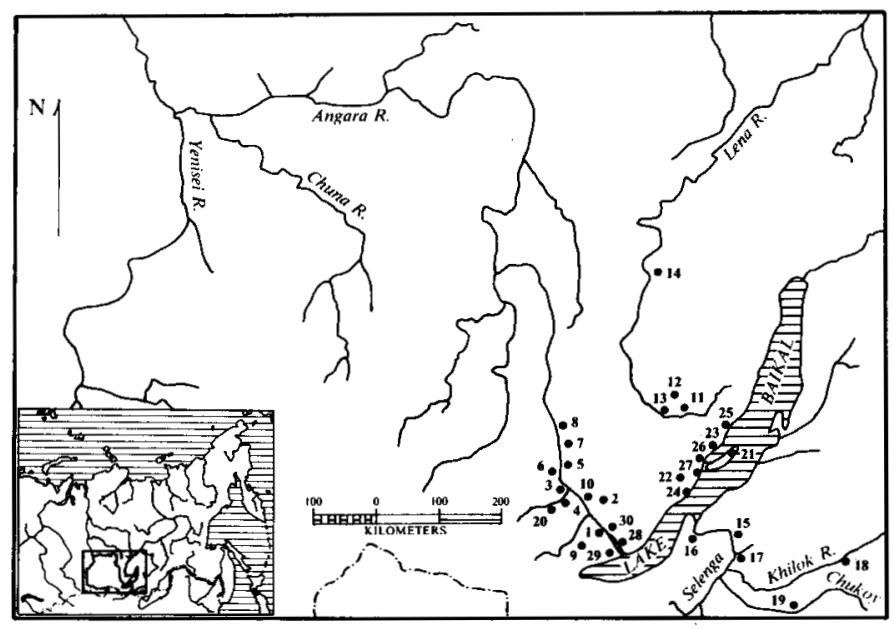

FIG. 1. Paleolithic and Mesolithic sites in the Baykal-Angara Region (modified after Konopatsky, 1982, and Michael, 1984): 1 - Mal'ta; 2 - Verkholenskaya Gora I and II; 3 - Ust' Belaya; 4 - Cheremushnik; 5 - Kulakovo; 6 Fedyayevo; 7 - Lenkovka; 8 - Krasnyy Yar; 9 - Sosnovyy Bor; 10 Buret'; 11 - The Makarovo sites; 12 - Shishkino Cliff; 13 - Shishkino site; 14 - Vodyanishnyy; 15 - Oshkurovo; 16 - Sannyy Mys; 17 - Staraya Bryan'; 18 - Tolbaga; 19 - Kunaley; 20 - Baday; 21 - Uzur; 22 Yelantsy; 23 - Kurminsky yegersky uchastok; 24 - Sagan-Zaba; 25 Ivanov Vzvoz; 26 - Bukhta Bazarnaya; 27 - Angasi-Yelaga; 28 - Kitoi; 29 - Chastye; $30-$ Khina. 
some poorly defined microlithic flint artifacts) and the appearance of fishing economies (e.g., fish spears [leisters], composite fishhooks and stone fish effigies). Okladnikov (1950) and, recently, Konopatsky (1982), on the basis of the distribution of stone representations of fish (Fig. 2) and analysis of the archaeological assemblages obtained from the prehistoric sites of the Baykal-Angara region, suggested that fish resources (particularly salmon) were present there since at least the sixth or seventh millennium B.C. and that these resources were "the principle means of livelihood" (Michael, 1958:54) for the ancient population of the Baykal-Angara region. Apparently this emphasis on fishing is reflected in the location and morphology of the habitation sites. BaykalAngara Mesolithic settlements were located very close to the river or to the shore on elevated floodplain terraces (Michael, 1958).

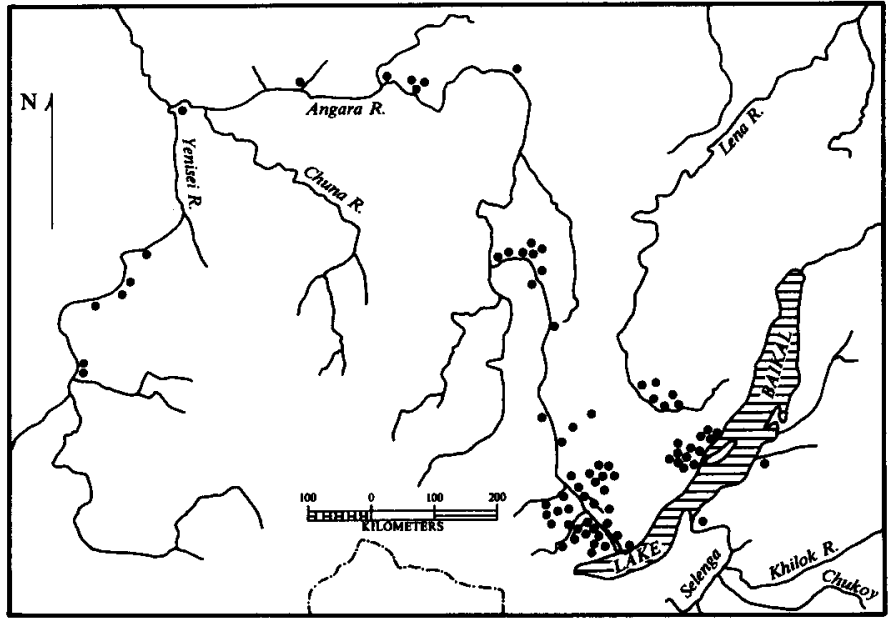

FIG. 2. Distribution of stone representations of fish in Baykal-Angara (modified after Michael, 1958).

\section{Ust' Belaya}

In this section I will offer a concise description of the Mesolithic sites Ust' Belaya and Cheremushnik which reveal the presence of a Mesolithic economy in the Cis-Baykal region, and also the method of analysis which Soviet archaeologists use to define a Mesolithic economy.

Ust' Belaya is one of the significant archaeological sites of the Siberian Mesolithic. It is located on the $8 \mathrm{~m}$ high river terrace on the left bank of the Belaya River, about $108 \mathrm{~km}$ northwest of Irkutsk (Fig. 1). In the stratified site of Ust' Belaya (Fig. 3) pre-Neolithic artifacts were found primarily in the lower horizon (layers VI, V, IV). M. Gerasimov, who first excavated this site in 1937, concluded, on the basis of the technotypological analysis of the stone assemblages, that layer VI was equivalent to the Azilian period. He found in this level six hearths in association with stone and bone artifacts (skreblos - large side scrapers - [Powers, 1973; Michael, 1984], endscrapers, harpoons, microcores, prismatic microblades), and modern fauna (wild goat, red deer, beaver, wolf, etc.). Sterile geological layers of about $60 \mathrm{~cm}$ separate layer VI from the socalled "Preceramic Neolithic"' layers (Medvedev, 1966).

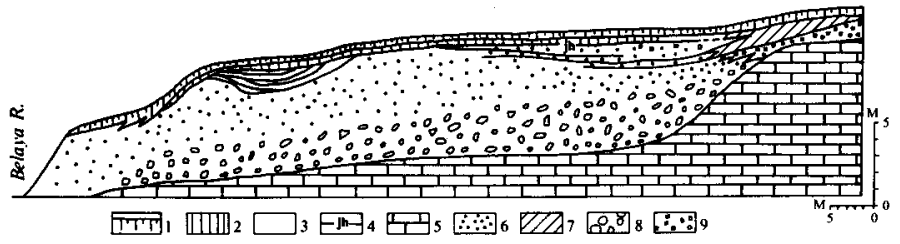

FIG. 3. Schematic cross section of the deposits of terrace 1 above the flood plain at the Ust' Belaya sites (modified after Medvedev, 1969): 1 - soil; 2 yellowish-brown sandy loam; 3 - numbers of the Mesolithic cultural layers; $4-$ amalgamated level in the middle portion of the terrace; 5 - Cambrian dolomites; 6 - flood-borne alluvia; 7 - deluvial deposits; 8 - pebble bed; 9 - pebbly Jurassic alluvium.

During 1957-59 Medvedev continued excavations of the lower layers of Ust' Belaya site. He discovered in layer VI at a depth of $180 \mathrm{~cm}$ several hearths in association with a few skreblos and large knives of the "Verkholensk" type, which were manufactured from prismatic blades. He also found microblades and microcores; for example, in layer $\mathrm{V}$ he found a "Gobi" type core - a distinctive type of wedge-shaped microblade core with a flat striking platform (Powers, 1973; Chard, 1974).

During the 1960-61 field seasons Medvedev extended the excavations. He was able to arrive at precise conclusions concerning the chronology of the lower horizon of the site. After analyzing the stone assemblages from layers VI, V, and IV, Medvedev concluded that they held no significant cultural differences, although the assemblage from the layer VI was cruder than the others. According to Medvedev (1966, 1969), the artifacts from layers $V$ and IV were manufactured from more symmetrical and prismatic blades than were those from layer VI (Fig. 4).

On the basis of technological-typological analysis and stratigraphic information, Medvedev $(1966,1969)$ concluded that the lower horizon of the Ust' Belaya site represents a

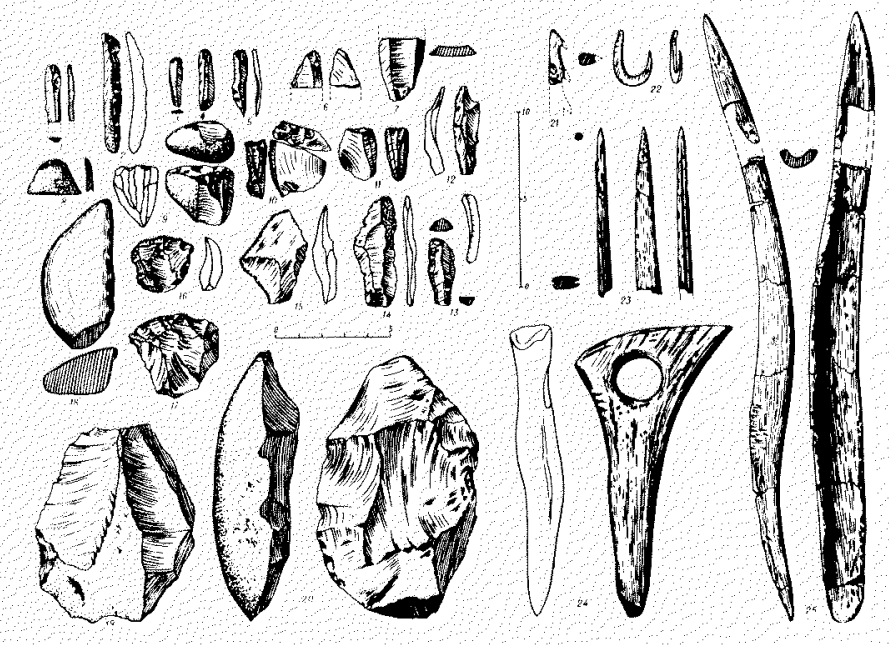

FIG. 4. Lithic and bone artifacts of layer V from Ust' Belaya (after Medvedev, 1966): $1-5$ - prismatic microblades; 6 - fragment of burin; $7,13-$ knifelike retouched blades; 8, 16, 17 - scrapers; 9-11 - wedge-shaped microblade cores; 12,14 - retouched blades; 15 - knife; 18 - pebblescraper; 19 - core from large pebble; 20 - preform of screblo; 21 - bone one side tougled harpoon head; 22 - fishhook; 23 - fragment of bone point; 24 - antler point; 25 - smoothed bone point. 
typical complex of the Siberian Mesolithic economy, exhibiting some obvious elements of the Paleolithic economy. He noted that geometric microliths did not occur at the site but that macrotechnology was widely developed, influencing the establishment of the Neolithic stone industry - adzes, axes, etc. (Medvedev, 1966). According to Medvedev $(1966,1969)$ and Aksenov (1969c), the stone artifacts of the lower horizon of the Ust' Belaya site ("Gobi"' cores, knives, harpoons, etc.) are identical to the late Mesolithic material from Verkholenskaya Gora (Fig. 4, 5).

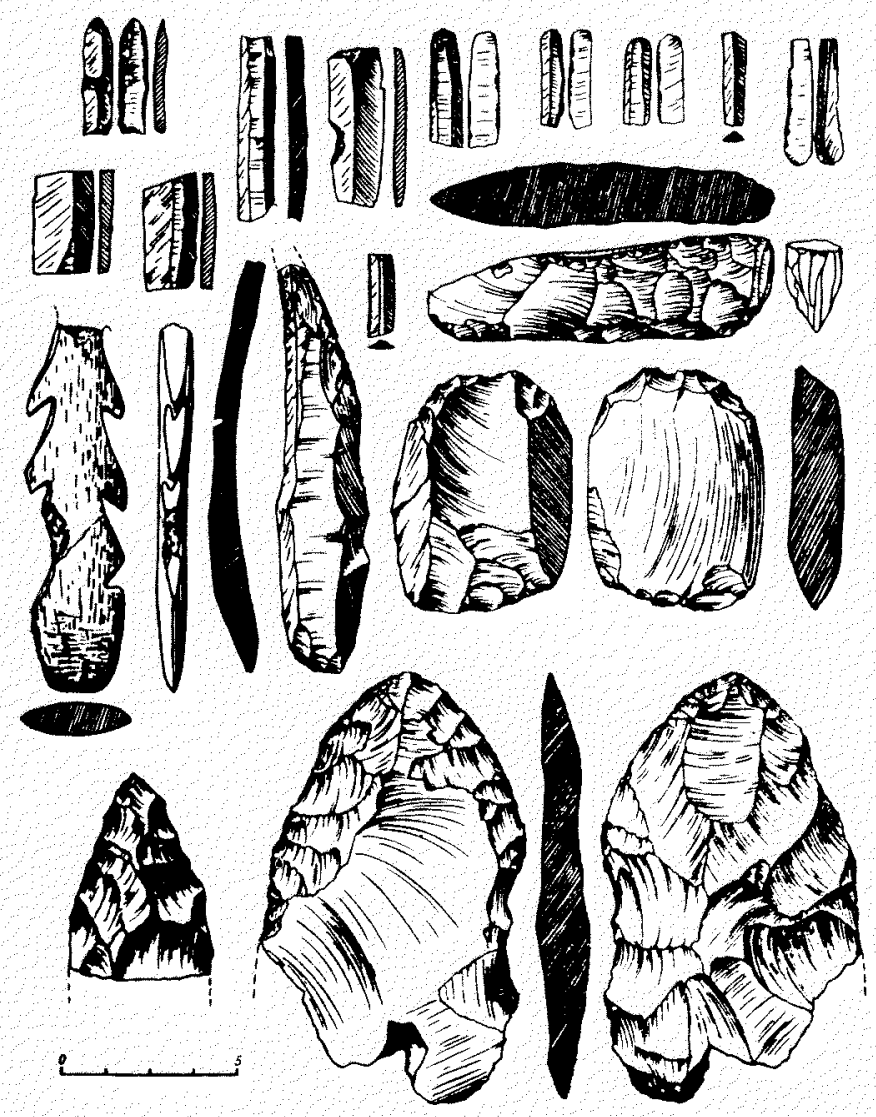

FIG. 5. Lithic and bone artifacts from Verkholenskaya Gora (after Medvedev, 1966).

\section{Cheremushnik}

Cheremushnik is another important Mesolithic site. It is located on the left bank of the Belaya River, about $3.5 \mathrm{~km}$ upstream from its confluence with the Angara (Fig. 1). Cheremushnik lies on the high $25-30 \mathrm{~m}$ river terrace, about 2-3 km north of the Baday archaeological site and $3-4 \mathrm{~km}$ southwest of the Ust' Belaya site.

Aksenov excavated this site in the mid-1960s and he noticed the occurrence of the projectile points and chiped almondshaped axes or adzes there. Pleistocene fauna significant for Mal'ta, such as mammoth, woolly rhinoceros, and arctic fox, are absent at Cheremushnik. Aksenov (1966, 1969a and $1969 \mathrm{~b}$ ) concluded that the lithic assemblage, specifically skreblos, axes, discoid cores and burins, from the Cheremushnik site was related to the assemblages from the lower horizon of Ust' Belaya and Verkholenskaya Gora. On the whole, based on the technological-typological analysis of the stone assemblages (presence of retouched rectangular microblades, which indicate the appearance of composite tools, appearance of flint arrow points manufactured from prismatic lamelar blades, and burins), faunal remains (absence of large Pleistocene mammals) and geomorphological data from the Quaternary geological layers, Aksenov concluded that the Ust' Belaya, Verkholenskaya Gora, Baday and Cheremushnik sites belong to the Mesolithic period and represent a "Cis-Baykal Mesolithic Complex" (Aksenov, 1969a:60). In his opinion the Cheremushnik site belongs to the Early Mesolithic stage or transitional link between the Late Paleolithic and Developed Mesolithic, when new game and new kinds of hunting equipment appeared. Its technique of working stone was later applied to Ust' Belaya and Verkholenskaya Gora. In sum, according to Aksenov (1969a:53), "the whole complex of tools from sites of the Badai culture points to hunting as the basis of the economy."

Although Siberian archaeologists are limited to the artifactual method of analysis for identification of a "Cis-Baykal Mesolithic Archaeological Complex" (Aksenov, 1966, 1969a, b, c; Medvedev, 1966, 1969), it becomes clear that Eurasian precepts for identification of Mesolithic sites (primarily the presence of geometric microlithics) are not applicable to Siberia, where the Mesolithic developed on the basis of the regional Late Paleolithic traditions and as a result of environmental and human adaptational changes. The Siberian Mesolithic does not provide any evidence for a common history with Eurasian geometric microlithic technology.

\section{THE ROLE OF FISHING ECOLOGY DURING THE LATE PLEISTOCENE-HOLOCENE "TRANSITION" PERIOD}

In the following sections I will discuss the potential application of the ecological and quantitative methods, based on the exploitation of fish resources, for identification of Mesolithic sites in the North during the Late Pleistocene-Early Holocene "transition."

Fish, particularly salmon, are one of the major resources of northern latitudes at present and probably were a significant resource for hunters and gatherers during the Late PleistoceneHolocene "transition" period in Siberia and the European Arctic. The salmon is a unique marine and freshwater species and probably appeared in high northern latitudes during the last deglaciation when the climatic changes occurred (Jochim, 1979). Unfortunately, salmon remains, as most fish remains, do not preserve well in the buried deposits of Early Holocene sites. Some archaeological evidence, however, suggests that Atlantic salmon were present in the Late Pleistocene of the Old World in the Birs Valley (Sarasin, 1918, cited in Jochim, 1979) and in the Rhine Valley of Central Germany (Jochim, 1979). Apparently climatic and geomorphological changes in the Late Pleistocene period affected the distribution and annual cycle of salmon behavior both in the Old and New Worlds, and presumably past salmon ecology was very similar to that of the present (Koo, 1962; Netboy, 1973). This theoretical alternative is based on the principle of uniformity, which states that 
a similar physical environment will create similar biological adaptations and behavioral strategies among non-human organisms.

Ecological; ethnographic and historic data (Rainey, 1939; Watanabe, 1969a,b, 1983; Balicki, 1976; Damas, 1968; Spencer, 1976; Fitzhugh, 1972; Nelson, 1973; Jochim; 1979; Krupnik, 1983) demonstrate that fishing, particularly anadromous, is a more efficient and reliable resource in most areas of northern latitudes, especially during summer, and that fishing played an: important role in supporting dense human populations in modern times as well as in the past. We can hypothesize that early Holocene hunters and gatherers would have maximized their hunting strategy - i.e., they increased their activities on more reliable resources and extensively utilized fish resources during favorable seasons. Freshwater and marine resources are a productive and predictable entity; which encourage, or allow, human populations to become sedentary as well as to increase their density and thus possibly influence a new type of social organization (Watanabe, 1969a,b; Cohen, 1977; Hayden, 1981; Lutz, 1983).

One can apply the assumption that during the Late Pleistocene-Holocene "transition" fishing became one of the major forms of human activity to the identification of Mesolithic sites in areas where a geometric microlithic technology is absent. If the "transition" sites do not yield strong archaeological evidence of fishing, i.e., faunal remains, fishing equipment, and processing tools, then the quantitative ecological methods of analysis such as Optimal Foraging Models (Pyke, et al., 1977; Smith and Winterhalder, 1981) may be proposed for measuring of the energy efficiency of certain ecosystems. These will define an interbiotic zone, i.e., a high concentration of food resources in a given ecosystem and during a specific season (Dolitsky, 1982, 1983, 1985). The main.hypothesis, which needs to be tested in many regions, is that where an interbiotic zone is designated, human adaptive strategies can be proposed. In applying the predictive model to local Mesolithic sites in the northern latitudes, I would concentrate in the areas where, for example, two or more (up to five) salmon spawning runs occur in a specific season. These areas can be identified as interbiotic zones for which salmon can potentially be a more efficient resource than any other available resource in an area.

As an example, relying on the paleoenvironmental (Ager and Sims, 1981a, b), ethnographic (Rainey, 1939) and salmon ecological data from south-central Alaska (State of Alaska, 1978), I was able to identify several potential macro-geographical locations in south-central Alaska (Gulf of Alaska area) where fishing sites, according to my model, should be found. (For a more detailed proposal to determine interbiotic zone, see Dolitsky, 1982 and 1983.)

Concerning site morphology, the type of sites associated with riverine resources would probably have been open-air and located along rivers, streams or lakes where major, concentrations of fish occurred. The boreal forest is also a likely location for fishing sites because forests can serve to protect people from cold, wind and rain. Coastal sites' morphology are deeply stratified and visible archaeologically since these sites were visited repeatedly over hundreds or even thousands of years, as fish are most easily caught in certain spots year after year (Trigger, pers. comm.).

\section{EXPLANATORY-PREDICTIVE SUBSISTENCE MODELS OF PREHISTORIC SETTLEMENT LOCATION}

Assuming that hunter-gatherer adaptive strategies in relation to their environment are based on rational decision-making principles, one can propose that a high proportion of the hunter and gatherer's activities will take place in areas where stable resources occur (Ackerman and Ackerman, 1973; Fitzhugh, 1972). . In other words, an archaeological site, representing a by-product of human activity (Yellen, 1977) and as "a geographical area containing a single unit, or a temporal sequence of single units, of human occupation" (Trigger, 1969:306), will be located in an area with high concentrations of resources at predictable times of the year. "Although the temporal and cultural affinities of the site may be a matter of inference, its geographical location cannot be in doubt" (Trigger, 1969:306). It is important to remember that the site, as a reflection of human activity, is always associated with physical or social phenomena that attract people to focus their activities there. Thus, I designate a geographical area with a high concentration of food resources in a specific season as an interbiotic zone (Dolitsky, 1982, 1983; Dolitsky and Plasket, 1985). This zone should not be thought of as belonging to a particular ecological niche or a stable ecozone, but it concerns the behavior of animals (their congregation, seasonal movements, habitat utilization, etc.) and the length of their prevailence in a particular geographical area. An interbiotic zone is not a static phenomenon and its designation depends on the variabilities and movements of living organisms within ecosystems - for example, when three mammal species are congregated in a certain geographical area during the fallwinter season and their behavior allows the inhabitants to hunt them successfully. Further, I would consider an interbiotic zone an area with promise of profitable utilization of its resources at a time when the animal population is high. Once the behavior of the animals in the area has changed and other potential resources for human exploitation occur in a different geographical area, then the interbiotic zone will change its location and attract hunters and gatherers to utilize the new biotic community. It follows that by being able to designate an interbiotic zone we can predict the probability of human occupation in a given area.

Some predictive models for locations of prehistoric sites in the northern hemisphere were recently formulated by Dixon (1979). Using a statistical-empirical method of analysis, Dixon noted that most archaeological sites of south-central Alaska are located in an ecotone area, i.e., forest tundra, the transitional zone between taiga and tundra ecosystems. Empirically speaking, most archaeological sites were found in the mountainous area of south-central Alaska on the border of the two ecosystems. To me, an explanation for the ecotone model is that forest tundra is extensively occupied by caribou and moose during a fall-winter-early spring season (State of Alaska, 1973; Pruitt, 1978; Novikov, 1981) and, therefore, 
these animals were the major subsistence resources for the Early Holocene hunters in the ecotone areas of south-central Alaska (Figs. 6 and 7). An important point not emphasized in Dixon's study for the explanation of the settlement pattern of the Early Holocene hunters and gatherers is that the relationship of archaeological sites to the physical environment is, first of all, a direct relationship of man to the efficient exploitation of food resources, a rich biotic community, in a given area. In describing a site's morphology, archaeologists traditionally focus on the fact that a site is located, for example, on the top of a hill. It is more meaningful, however, to say that human activity occurred on the top of the hill, reflecting "particular cases of patterned behavior" (Gould, 1971:144, 175 ) and "local social groups instead of cultures or phases", (Chang, 1967:151). Thus, to understand human/environment relationships, one must begin to understand both the behavioral patterns in an ecosystem and also the interactions between human activity and surrounding subsistence resources.

Interbiotic zone locational analyses are methodologically

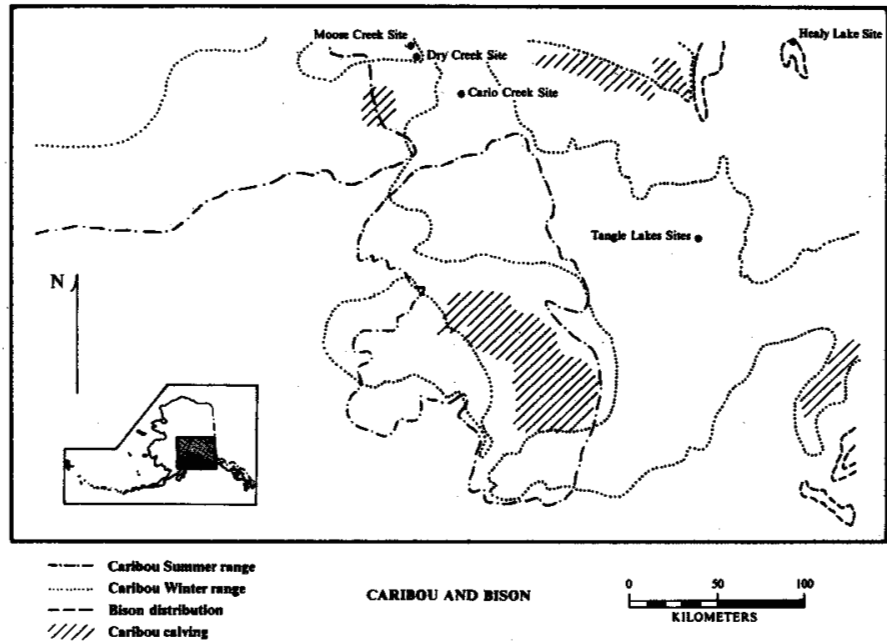

FIG. 6. Distribution of caribou and bison in south-central Alaska (includes four physiographic provinces of Alaska: Alaska Range, Susitna-Cook Inlet Lowland, Copper River Plateau and Talkeetna Mountains).

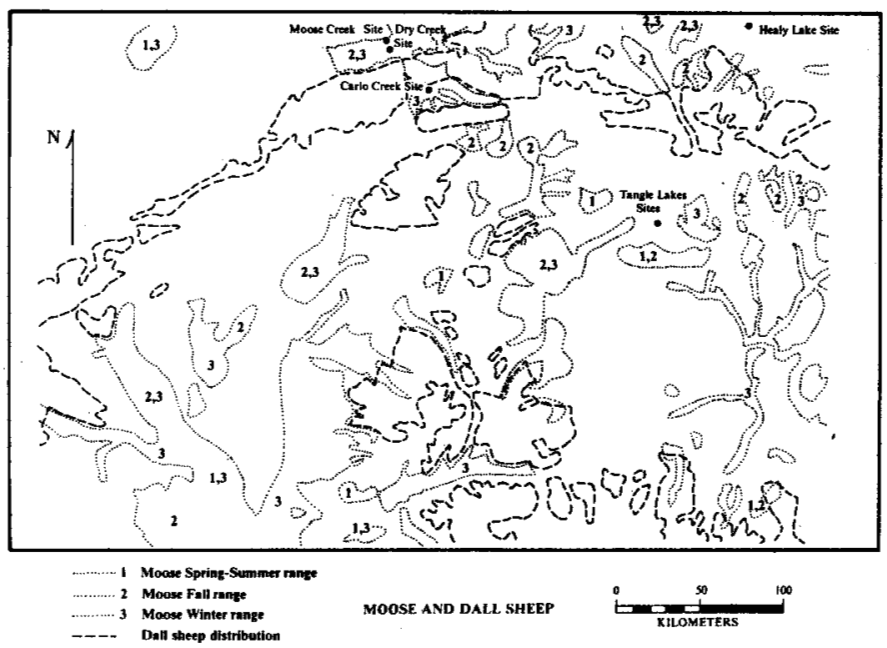

FIG. 7. Distribution of moose and Dall sheep in south-central Alaska. relevant to the maximization principles of human behavior (Jochim, 1976, 1979, 1981) and the ecological-psychological approach in anthropology, namely decision-making behavior (Frake, 1962; Bennett, 1976), which provide significant insight into human evolution and adaptation. Jochim has outlined a comprehensive approach to hunter-gatherer adaptation, resting ultimately on a predictive model of the use of resources. He assumes that resources are exploited in proportion to the ability to satisfy two basic subsistence goals: (1) attainment of a secure income; (2) maintenance of population aggregation at low cost. In a broad sense, the model developed by Jochim $(1976,1981)$ is an example of a larger field of economic study that approaches decision-making as a central problem of analysis. In archaeology, Jochim's "goal satisfaction model" is useful as a tool for studying settlement location and territoriality. For example, in an attempt to define the role of salmon in a Mesolithic economy of hunter and gatherer populations in southwestern Germany, Jochim (1979:224) structures several ethnographic models based on the following premises:

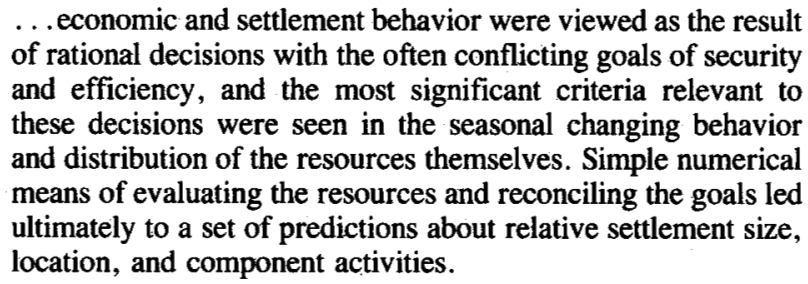

In reconstructing the seasonal distribution of salmon and major environmental categories in an area, Jochim proposes that ". . camps would have been placed in zones of overlapping distribution of resources for each season" (Jochim, 1979:229) and also that camps have been situated closer to the less mobile resources. These areas of probable settlement location ". . can be presented in the form of potential catchment areas around the overlap zones using a radius of ten kilometers"' (Jochim, 1979:229).

Another locational analysis of northern people, proposed by Watanabe (1969a,b, 1977), is based on man's ability to adjust intellectually to his environment. In order to define the relationship between the mode of subsistence of hunters and gatherers and their behavioral strategy (i.e., why people choose what they choose and under what circumstances do hunters-gatherers occupy a particular geographical location [site] as a habitation), Watanabe has emphasized research on the understanding of individual behavior, based on maximization decision-making principles of human rationale (Watanabe, 1977):

For the scientific study of human life it is first necessary to reveal its structure, and then to clarify its function. It is of fundamental importance that life of the individual be investigated to understand the life of a people, just as it is necessary to investigate the physique of the individual to understand the physique of people; and that the life of the individual consists of various interrelated activities, as is clearly indicated by observations of the lives of animals in the fields. Thus, field study of the daily activities of the individual is the starting point of the scientific study of the life of man. (Watanabe, 1977:4.) 
In his study of Ainu hunter and gatherer groups, Watanabe (1969a) was also interested in examining settlement patterns with reference to resources and in clarifying the concept of nomadism and sedentarism. He has been able to determine five ecological zones with specific resources where Ainu activities have occurred in specific seasons:

1. The river: cherry salmon fishing (summer, in the main stream and some tributaries); dog salmon fishing (autumn, in the main stream). 2. The river banks: collecting of wild plants (spring to autumn). 3. The river terraces: deer hunting (autumn); plant collecting (spring to autumn); human habitation (all year). 4. The hillsides along the river course: deer hunting (early winter, at or near the animals' winter quarters). 5. The mountain region around the source of the river: bear hunting, specialized (spring and autumn); collection of elm bark for clothing (usually spring). (Watanabe, 1969a:72.)

His main conclusion is that a food-shortage among northern hunters and gatherers has been the limiting factor relevant to population pressure and this has determined the spatial and temporal structure and strategy of their activities and mode of life (Watanabe, 1969a,b, 1977, 1983).

In sum, the determinants of site location for huntersgatherers are strongly dependent on subsistence adaptation, so that a truly general predictive model of location must be accompanied by a predictive model of subsistence behavior. In this sense, the only comprehensive model in contemporary archaeology is the maximization model proposed by Jochim (1976 and 1981) and the spatial-temporal structure of Watanabe (1977).

The interbiotic zone model can be analyzed in terms of what is efficient on purely energy grounds, or in terms of careful computation of efficient budgeting of both the time of occupation of geographical area by animals and the optimal animal behavioral processes (migration, seasonality, reproduction, etc.). Of major importance is the finding that where an interbiotic zone may be designated, human adaptive strategies also may be proposed. The implicit assumption of the interbiotic zone model is that human selection will tend to maximize the best-fitting choices (Jochim, 1976, 1979, 1981). Thus, by determining that fishing in a certain season and in a certain ecosystem is more efficient than any other hunting-gathering activity, we can uniformly propose that fishing economies played a major role during the Late Pleistocene-Holocene "transition" in some arctic and subarctic regions and that Post-Pleistocene archaeological sites associated with such activities can be classified as Northern Mesolithic.

\section{CONCLUSION}

It is apparent that most Soviet archaeologists, including those who specialize in Siberian archaeology, are limited to the traditional technological-typological approach for the analysis of archaeological data and the explanation of cultural change. The principles of ecological anthropology (Jochim, 1976, 1981; Watanabe, 1983), the ecological-psychological approach (Frake, 1962; Bennett, 1976), and the quantitative ecological methods of analysis such as the Optimal Foraging Models (Smith and Winterhalder, 1981) have not yet been ex- tensively applied to or tested for the Soviet subarctic and arctic regions. The traditional orientation of most Siberian archaeologists lacks both comparative analyses and correlations of the archaeological data of diverse geographical regions.

In this research paper I suggest an ecological method with reference to the fishing economy for the classification of the Siberian Mesolithic (food-gathering stage) that differs from the technological-typological method of classification. (The possible reconsideration of the classification of a foodproducing economy in Siberia using an economic-ecological method is also suggested.) The proposed method is based on the principles of adaptive strategy of early hunters and gatherers in relation to certain factors: (1) subsistence resources play dominant roles in their economy during certain times of the year, and (2) so does the ecosystem.in which these resources are then formed. The interaction of hunters and gatherers with local subsistence resources in the arctic and subarctic regions influenced technology, site morphology, social organization, and varieties of utilization of the subsistence resources.

Therefore, in order to understand human settlement systems properly, we must study the physical environment, ethology, and ecological relationship between human actions and subsistence resources within a given geographical location. It is within this geographical unit that people tend to concentrate their food-getting activities and as a result are likely to develop sufficient knowledge of the location of various resources to anticipate the timing of availability. Once we have detailed these relationships, we have set the stage for other types of studies, such as measurements of ecological efficiency, which are necessary for a proper scientific approach to the study of human behavior.

In this research, I regard the concept of "ecotone" as less productive for the analysis of site locations than the concept of "interbiotic zone," since the ecotone concept is not directly related to human behavior. However, interbiotic zone appears to subsume what is useful in the concept of ecotone because it is defined directly in terms of human adaptive strategies. The interbiotic zone approach was presented here on a very broad theoretical level and the potential of the approach was not fully developed. However, it would be interesting to see the outcome of this approach applied to a full analysis of subarctic and arctic regions.

\section{ACKNOWLEDGEMENTS}

I would like to express my thanks to Henry N. Michael, Museum Applied Science Center for Archaeology, University Museum, University of Pennsylvania, and Jacob Gruber, Visiting Professor, Department of Anthropology, University of Pennsylvania, for useful comments and discussions on this paper. Dr. Richard Gould (Brown University), Dr. B. Wailes (University of Pennsylvania), Dr. Bruce Trigger (McGill University), Dr. Donald Clark (Museum of Man, Ottawa), Dr. Hitoshi Watanabe (Hokkaido University, Sapporo), and Ph.D. candidate David Plasket (Brown University) all made valuable comments regarding some of the theoretical approaches presented here. 


\section{REFERENCES}

ACKERMAN, R.E., and ACKERMAN, L.A. 1973. Ethnoarchaeological Interpretations of Territoriality and Land Use in Southwestern Alaska. Ethnohistory 20(3):315-346.

AGER, T.A., and SIMS, J.D: 1981a. Holocene Pollen and Sediments Record from the Tangle Lakes Area, Central Alaska. Palynology 5:85-98.

1981b. Late Quaternary Pollen Record from Hidden Lake, Kenai Peninsula, Alaska. Fourteenth Annual Meeting. New Orleans, Louisiana: American Association of Stratigraphic Palynologists Inc. 8-9.

AKSENOV, M.P. 1966. "Stoyanka Cheremushnik: k voprosu o meste Babayskoy kul'tury v kamennom veke Pribaikal'ya (Cheremushnik: Toward the Problem of the Babay.Culture in the Stone Age of the Cis-Baykal). Sibirskiy Arkheologicheskiy Sbornik. Vypusk 2. Novosibirsk: Nauka. 23-37.

1969a. Archaeological Investigations of the Early Mesolithic Site of Cheremushnik. Arctic Anthropology 6(1):45-49.

$1969 \mathrm{~b}$. The Cheremushnik Site: a contribution to the problem of the place of the Badai culture in the stone age of the Cis-Baikal. Arctic Anthropology 6(1):50-60.

$1969 \mathrm{c}$. Archaeological Investigations at the Stratified Site Verkholenskaya Gora. Arctic Anthropology 6(1)74-87.

ANDRIANOV, P.M. 1974. Geograficheskya Sreda i Problema Zarozhdeniya Zemledeliya (Geographical Environment and the Origin of Agriculture). In: Pervobytnyy Chelovek i Prirodnaya Sreda (Ancient Man and Environment). I.P. Gerasimov, ed. Moscow: Nauka. 217-224

BADER, O.N. 1974. Problema Smechsheniya Landshaftnykh Zon v Golotsene i Arkheologiya (Changes of the Landscape Zones in the Holocene and Archaeology). In: Pervobytnyy Chelovek i Prirodnaya Sreda (Ancient Man and Environment). I.P. Gerasimov, ed. Moscow: Nauka. 225-230.

BALIKCI, A. 1976. The Netsilik Eskimo. Garden City, New York: The Natural History Press. $264 \mathrm{p}$.

BENNETT, J.W. 1969. Northern Plainsmen: Adaptive Strategy and Agrarian Life. Chicago: Aldine. $385 \mathrm{p}$.

1976. The Ecological Transition: Cultural Anthropology and Human Adaptation. New York: Pergamon Press Inc. 372 p.

BRAIDWOOD, R.I. 1960. Levels in Prehistory: A Model for the Consideration of the Evidence. In: Evolution after Darwin. Vol. 2. The Evolution of Man. T. Sol, ed. Chicago: University of Chicago Press. 143-151.

CHANG, K.C. 1967. Rethinking Archaeology. New York: Random House. $172 \mathrm{p}$.

CHARD, S. 1974. Northeast Asia in Prehistory. Madison: The University of Wisconsin Press. 214 p

CHERNYSH, O.P. 1975. Starrodavne Naselennya Podnistov'ya v Dobu Mesolitu (Ancient population along the lower Dnieper River during the Mesolithic). Kiev: Naukova Dumka. 165 p.

CHILDE, V.G. 1957. The Dawn of European Civilization. 6th ed. London: Cambridge University Press. 328 p.

CLARK, G.D. 1952. Prehistoric Europe: The Economic Basis. New York: Philosophical Library. $349 \mathrm{p}$.

1972. Star Carr: A Case Study in Bioarchaeology. McCaleb Module in Anthropology 10. Chicago: Addison-Wesley. $42 \mathrm{p}$.

COHEN, M.N. 1977. The Food Crisis in Prehistory: overpopulation and the origins of agriculture. New Haven: Yale University Press. 342 p.

DAMAS, D. 1968. The University of Eskimo Societies. In: Man the Hunter. R.B. Lee and I. De Vore, eds. Chicago: Aldine. 111-117.

DIXON, J. 1979. A Predictive Model for the Distribution of Archaeological Sites on the Bering Continental Shelf. Unpublished $\mathrm{Ph} . \mathrm{D}$. thesis, Department of Anthropology, Brown University, Providence, R.I. 02912. 248 p.

DOLITSKY, A.B. 1982. Structural-Ecological Approach to the Archaeology of the Wisconsinian-Holocene "transition" Period in South-Central Alaska. Unpublished ms. $120 \mathrm{p}$.

1983. An Ecological Approach to the Archaeology of the Wisconsinian-Holocene "transition"' Period in South-Central Alaska. -Unpublished M.A. thesis, Department of Anthropology, Brown University, Providence, R.I. 02912. $101 \mathrm{p}$.

and PLASKET, D. 1985. Subsistence, Environment and Society: New Directions in Ecological Anthropology. Ultimate Reality and Meaning 8(2): 105-122.

DOLUKHANOV, P.M., and KHOTINSKY, N.A. 1974. Paleograficheskiye Rubezhi Golotsena i Mezo-Neoliticheskaya Istoriya Yevropy (Paloegeo- graphic Dimensions of the Holocene and the Meso-Neolithic History of Europe). In: Pervobytnyy Chelovek i Prirodnaya Sreda (Ancient Man and Environment). I.P. Gerasimov, ed. Moscow: Nauka. 211-217.

EFIMENKO, P. 1953. Pervobytnoye obcshestvo (Ancient Society) 3rd. ed. Kiev: Naukova Dumka. 563 p.

FITZHUGH, W.W. 1972. Environmental Archaeology and Cultural Systems in Hamilton Inlet, Labrador: Smithsonian Contributions to Anthropology, 16. Washington, D.C. 299 p.

FRAKE, C.O. 1962. Cultural Ecology and Ethnography. American Anthropologist 64:53-58

GIDDINGS, L.J. 1967. Ancient Men of the Arctic. New York: Alfred A. Knopf Inc. 383 p.

GOULD, R:A. 1971. The Archaeologist as Ethnographer: a case from Western Australia. Southwestern Journal of Anthropology 24(2): 101-122.

GURINA, N.N., KOSHECHKIN, B.I., and STRELKOV, S.A. 1974. Pervobytnye Kul'tury i Evolyutsiya Ekologicheskoy Obstanovki v Verkhnem Pleistotsene i Golotsene na Poberezh'yakh Yevropeyskoy Arktiki (Ancient Cultures and Ecology of the Coastal European Arctic during the Upper Pleistocene and Holocene). In: Pervobytnyy Chelovek i Prirodnaya Sreda (Ancient Man and Environment). I.P. Gerasimov, ed. Moscow: Nauka. 231-234.

HARRIS, M. 1968. The Rise of Anthropological Theory: a history of Theories of Culture. New York: Columbia University Press. $764 \mathrm{p}$.

HAYDEN, B. 1981. Research and Development in the Stone Age: Technological Transitions among Hunter-Gatherers. Current Anthropology 22(5):519-548.

JOCHIM, M.A. 1976. Hunter-Gatherer Subsistence and Settlement: A Predictive Model. New York: Academic Press. 206 p.

1979. Catches and Cashes: Ethnographic Alternative for Prehistory. In: Ethnoarchaeology - Implications of Ethnography for Archaeology. C. Kramer, ed. New York: Columbia University Press. 219-246.

1981. Strategies for Survival: Cultural Behaviour in an Ecological Context. New York: Academic Press. 234 p.

KHLOBYSTIN, L.P., and LEVKOVSKAYA, G.M. 1974. Rol' Sotsial'nogo i Ekologicheskogo Faktorov v Razvitii Arkticheskikh Kul'tur Yevrazii (The Role of the Social and Ecological Factors in the Development of the Arctic Cultures of Eurasia). In: Pervobytnyy. Chelovek i Prirodnaya Sreda (Ancient Man and Environment). I.P. Gerasimov, ed. Moscow: Nauka. 235-241.

KONOPATSKY, A. 1982. Kamennyy vek pribaykal'ya (Stone Age of CisBaykal). Novosibirsk: Nauka. 208 p.

KOO, S.Y., ed. 1962. Studies of Alaska Red Salmon. Seattle: University of Washington Press. 449 p.

KOZLOWSKI, S.K. 1973. The Mesolithic in Europe. Warsaw: University Press. $699 \mathrm{p}$.

KRUPNIK, I.I. 1983. Drevniye i traditsionnye poseleniya eskimosov na yugo-vostoke chukotskogo poluostrova (Early Eskimo Settlements in the southeast of Chukchi Peninsula). In: Na Styke Chukotki i Alyaski (Contacts between the Chukchi Peninsula and Alaska). V.P. Alekseyev et al., eds. Moscow: Nauka. 65-95.

LUTZ, B. 1983. Population Pressure and Climate as Dynamics within the Arctic Small Tool Tradition of Alaska. Arctic Anthropology 19(2):143149.

MARTYNOV, A.I. 1981. Arkheologiya SSSR (Archaeology of the USSR) Moscow: Vysshaya Shkola. $297 \mathrm{p}$.

MATYUSHIN, G.N. 1976. Mesolit Yuzhnogo Urala (The Mesolithic of southern Urals). Moscow: Nauka. 310 p.

MEDVEDEV, G.I. 1966. Novye Dannye o nizhnikh sloyakh Ust' Beloy (New Data on the Lower Horizon of the Ust' Belaya). Sibirskiy Arkheologicheskiy Sbornik, Vypusk 2. Novosibirsk: Nauka. 38-52.

1969. Results of the Investigation of the Mesolithic in the Stratified Settlement of Ust'Belaya 1957-1964. Arctic Anthropology 6(1):6174.

MICHAEL, H. 1958. The Neolithic Age in Eastern Siberia. Philadelphia: American Philosophical Society. Vol. 48. Part 2. 108 p.

1984. Absolute Chronologies of Late Pleistocene and Early Holocene Cultures of Northeastern Asia. Arctic Anthropology 21(2):1-105.

MURPHEY, R. 1972. The Scope of Geography. Chicago: Rand McNally and Company Press. $177 \mathrm{p}$.

NELSON, R. 1973. Hunters of the Northern Forest. Chicago: University of Chicago Press. 339 p. 
NETBOY, A. 1973. The Salmon: The Fight for Survival. Boston: Houghton Mifflin Company. 322 p.

NOVIKOV, G.A. 1981. Zhizn' na Snegu i pod Snegom (Life on and below the Snow). Leningrad: Leningrad University Press. 191 p.

OKLADNIKOV, A.P. 1950. The Neolithic and Bronze Age in the Baykal. Materialy i Issledovaniya po Arkheologii. No. 18. Moscow: Nauka. $411 \mathrm{p}$.

1983. Pribrezhnaya mesoliticheskaya stoyanka Artemovka 1 (Coastal Mesolithic Settlement Artemovka 1). In: Issledovaniya Mesolita i Neolita v SSSR (Studies of the Mesolithic and Neolithic in the U.S.S.R.). Leningrad: Nauka. 5-13.

PANKRUSHEV, G.M. 1978. Mesolit i Neolit Karelii (Mesolithic and Neolithic of Karelia). Vol. 1. Leningrad: Nauka. 165 p.

POWERS, W.R. 1973. Paleolithic Man in Northeast Asia. Arctic Anthropology $10(2): 1-106$.

PRICE, T.D. 1983. The European Mesolithic. American Antiquity 48(4):761-778.

PRUITT, W.O. 1978. Boreal Ecology. Southampton: Camelot Press Ltd. $152 \mathrm{p}$.

PYKE, G.H., PULLIAM, H.R., and CHARNOV, E.I. 1977. Optimal Foraging: A Selective Review of Theory and Tests. The Quarterly Review of Biology 52(2): 137-154.

RAINEY, F. 1939. Archaeology in Central Alaska. Anthropological Papers of the American Museum of Natural History. New York. Vol. 36:351-405.

SAVUKINENE, N.P., and SEYBUTIS, A.A. 1974. Vliyaniye Subatlanticheskogo Ukhudsheniya Klimata na Razvitiye Zemledeliya $v$ Litve $v$ Svete Palinologicheskikh Dannykh (Influence of the Subatlantic Climate on the Development of Agriculture in Lithuania on the Basis of Palinology). In: Pervobytnyy Chelovek i Prirodnaya Sreda (Ancient Man and Environment). 1.P. Gerasimov, ed. Moscow: Nauka. 247-250.

SEMENOV, S.A., and KOROBKOVA, G.F. 1983. Tekhnologiya Drevneyshikh Proizvodstv: Mesolit i Eneolit (Ancient Technology: Mesolithic and Eneolithic). Leningrad: Nauka. 253 p.
SMITH, E.A., and WINTERHALDER, B.P. 1981. Hunter-Gatherer Foraging Strategies: Ethnographic and Archaeological Analyses. Chicago: University of Chicago Press. 268 p.

SPENCER, F. 1976. The North Alaskan Eskimo: A Study in Ecology and Society. New York: Dover Publications Inc. 490 p.

STARKOV, V.F. 1980. Mezolit i Neolit lesnogo zaural'ya (Mesolithic and Neolithic of the Trans-Ural Woodland Regions). Moscow: Nauka, 217 p.

STATE OF ALASKA. 1973. Alaska's Wildlife and Habitat. Vol. 1. Anchorage: State of Alaska, Department of Fish and Game.

1978. Alaska's Fisheries Atlas. Vol. I. Anchorage: State of Alaska, Department of Fish and Game.

TRIGGER, B.G. 1969. Criteria for Identifying the Locations of Historic Indian Sites: A Case Study from Montreal. Ethnohistory 16(4):302-316.

TSEYTLIN, S.M. 1979. Geologiya paleolita severnoy Azii (The Geology of the Paleolithic of northern Asia). Moscow: Nauka. 285 p.

WATANABE, H. 1969a. Subsistence and Ecology of Northern Food gatherers with Special Reference to Ainu. In: Man the Hunter. R. Lee and I. De Vore, eds. New York: Columbia University Press. 69-77. 1969b. Famine as a Population Check. Comparative Ecology of Northern Peoples. Journal of the Faculty of Science. University of Tokyo. Sec. V. Vol. III. Part 4:237-252.

1977. The Human Activity System and Its Spatiotemporal Structure. In: Human Activity System: Its Spatiotemporal Structure. H. Watanabe, ed. Tokyo: University of Tokyo Press. 5-39.

1983. Occupational Differentiation and Social Stratification: The Case of Northern Pacific Maritime Food-Gatherers. Current Anthropology 24:217-219.

YELLEN, J.E. 1977. Archaeological Approaches to the Present: models for reconstructing the past. National Museum of Natural History. Washington, D.C.: Smithsonian Institution. 259 p.

ZHURAVLEV, A.P. 1983. Mezoliticheskoye Poseleniye Pergema VIII v Karelii (The Mesolithic Settlement Pegrema VIII in Karelia). In: Issledovaniya Mezolita i Neolita v SSSR (Studies of the Mesolithic and Neolithic in the U.S.S.R.). Leningrad: Nauka. 39-43. 